\title{
Acute Histopathological Response of Renal Tissues After Varied Fractionated Abdominal 12 Gy Irradiation In Rats
}

\author{
Hakan Akdere
}

Department of Urology, Trakya University Faculty of Medicine, Edirne, Turkey

Submitted: 24.03.2017 Accepted: 10.04.2017

Correspondence: Hakan Akdere, Mimar Sinan Mah., Maxi Karşısı, Sunflowe Sitesi, İkiz Evler, No: 23, Silivri, İstanbul, Turkey E-mail:hakdere@yahoo.com

Keywords: Hypofractionated radiotherapy; irradiation damage; radiotherapy; renal tissue

\begin{abstract}
Objective: The aim of the present study was to evaluate the effect of fraction dose irradiation on kidney damage due to scattered radiation.
\end{abstract}

Methods: Rats were randomized into 6 groups. Group I: Control group, a sham irradiation $(n=5)$; Group 2: Hypofractionated total abdominal irradiation (TAl), total of 12 Gy (2 fractions in 2 days) ( $n=4)$; Group 3: Hypofractionated TAI, total of 12 Gy (3 fractions in 3 days; $\mathrm{n=6}$ ); Group 4: Hypofractionated TAI, total of 12 Gy (4 fractions in 4 days; $n=6$ ); Group 5: TAI with conventional fractionation, total of 12 Gy ( 6 fractions in 6 days; $n=6)$; and Group 6: TAI with conventional fractionation, total of 12 Gy (7 fractions in 7 days; $n=6$ ).

Results: There was no statistically significant difference $(p>0.05)$ between the hypofrac-

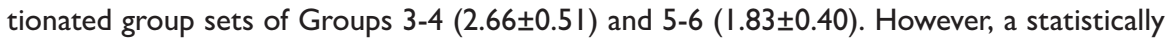
significant difference was found in the comparison between Group $2(3.75 \pm 0.5 \mathrm{I})$ and the group sets of Groups 3-4 and 5-6 ( $<<0.05)$.

Conclusion: The present study demonstrated that hypofractionated TAl leads to more prominent acute tissue damage in the kidneys than does conventional irradiation.

\section{INTRODUCTION}

Radiation therapy (RT) is an important treatment modality in abdominal malignancies. Kidneys, by limiting the dose, restrict the application of irradiation on abdominal area. Morphological studies on radiation nephropathy have demonstrated injuries to blood vessels, glomeruli, tubular epithelium, and interstitium. Data about kidney-dose response has shown that doses of 18-23 Gy and $28 \mathrm{~Gy}$ in 0.5 to $1.25 \mathrm{~Gy} /$ fraction were associated with a $5 \%$ and $50 \%$ risk of injury at 5 years, respectively. ${ }^{[1]}$ Even with dose-fractionation approaches, radiation-induced kidney damage cannot be completely eliminated. Prophylactic radioprotectant use before irradiation may be an alternative way to reduce the kidney damage in these patients.

Free radicals can lead to damage in the DNA, proteins, and lipids. The effect of ionizing radiation is thought to be mediated through the action of these free radicals. Accordingly, antioxidative defense mechanisms are accountable for the vast majority of the damage caused by radiation. ${ }^{[2]}$
Conventional RT regimens usually involve an application of 1.8 to $2.0 \mathrm{~Gy} /$ day; there are also daily treatment programs in which the application is carried out by decreasing the number of fractions. ${ }^{[2,3]}$ Within the scope of daily conventional RT, hypofractionated treatments currently used in some malignancies may be preferred due to their potential effect, as well as the short treatment duration and smaller side effect profile. ${ }^{[4]}$ In spite of these developments however, the surrounding tissues and organs are still more or less subjected to harmful effects.

While reducing the dosage and the frequency in order to provide protection against the harmful effects of radiation, it is also important to maintain a dosage that will be effective on malignant cells. During the treatment process, the sensitivity that develops in radiosensitive organs despite low dosage should be taken into consideration as well. The most important element among these organs is the renal tissue; pathological changes in this tissue start immediately, even if the dosage is low. ${ }^{[5]}$ lonized radiation disrupts the normal metabolic activities in cells by causing 
proliferation and differentiation. This leads to apoptosis and necrosis development, particularly in radiosensitive cells. This effect then reveals itself on the kidneys through glomerular pathologies. These pathologies bring to mind the lesions formed by glomerulonephritis and chronic pyelonephritis. Radiation nephropathy occurs together with arterial lesions. Large blood vessels are affected in later stages. ${ }^{[2]}$ Researchers have identified the changes that occur following renal irradiation. These changes include a decrease in total renal mass, sclerosant changes in arcuate arteries, significant occlusion of the glomerular capillary network, glomerular hyalinization, and progressive tubule atrophy. All of these changes are significantly interrelated with interstitial fibrosis. ${ }^{[2]}$

Whether a pathology is permanent or transient, it is directly correlated with radiation dosage and duration. ${ }^{[5,6]}$ Glomeruli are especially sensitive to irradiation; doses as low as 0.1 Gy lead to temporary reduction in the number of glomeruli endothelia, and $0.15 \mathrm{~Gy}$ leads to temporary renal failure. Azotemia lasting for several years occurs after $2 \mathrm{~Gy}$, and permanent azotemia occurs after approximately 10 to 12 Gy in 2 Gy fractions. ${ }^{[5]}$

Erythropoietin released from the kidneys affects the late progenitor cells of the erythrocyte series as a growth and survival factor and prevents their apoptosis. It also enables these cells to be carried to the differentiation stages at a later time, and this results in the production of erythrocytes. Cells resembling fibroblasts are also produced in the interstitial spaces between the tubuli of the renal cortex, which is one of the reasons for the interstitial fibrosis that develops due to RT. ${ }^{[7]}$

Glomerular endothelium and tubular epithelium are extremely sensitive to irradiation. Damage occurs particularly in $3 \mathrm{~Gy} / \mathrm{I}$, and is maximized in $6 \mathrm{~Gy} / \mathrm{I}(3)$.

The results of studies that compared the acute and delayed toxicities of conventional RT and hypofractionated RT are not fully consistent. In this study, the aim was to evaluate the effect of fraction dose on the damage in Wistar albino rat kidneys due to scattered radiation.

\section{MATERIAL AND METHODS}

\section{Animals and experimental design}

The guidelines of the Institutional Animal Care and Use Committee were followed in all animal experiments. Thirty-six Wistar albino rats, weighing from 200 to $230 \mathrm{~g}$ each, were housed in rat cages. Ad libitum access to standard rodent diet and tap water was provided.

Cages were maintained in a light cycle of 12 hours of light and 12 hours of darkness at a mean temperature of $21 \pm 2^{\circ} \mathrm{C}$ and a mean humidity of $55 \pm 2 \%$. When they had reached 3 weeks of age, the rats were randomized into 6 groups.
Group I: Control group, a sham irradiation $(n=5)$; Group 2: Hypofractionated total abdominal irradiation (TAl) with irradiation therapy of $6 \mathrm{~Gy} / \mathrm{I}$ fraction/day applied for 2 days, totaling 12 Gy (2 fractions in 2 days; $n=4$ ); Group 3: Hypofractionated TAl with irradiation therapy of $4 \mathrm{~Gy} / \mathrm{I}$ fraction/ day given in 3 days for a total 12 Gy $(3$ fractions in 3 days; $\mathrm{n=6}$ ); Group 4: Hypo-fractionated TAl with $3 \mathrm{~Gy} / \mathrm{l}$ fraction/ day, totaling 12 Gy (4 fractions in 4 days; $n=6$ ); Group 5: TAl with conventional fractionation of $2 \mathrm{~Gy} / \mathrm{l}$ fraction/day for a total 12 Gy (6 fractions in 6 days; $n=6$ ); and Group 6: TAl with conventional fractionation of $1.7 \mathrm{~Gy} / \mathrm{l}$ fraction/ day, totaling 12 Gy (7 fractions in 7 days; $n=6$ ).

During the study, I rat in the first group and 2 in the second group died, possibly due to the effects of radiation, and they were excluded from the study. The subjects were under anesthesia during all experimental procedures. Intramuscular injection of ketamine and xylazine $(50 \mathrm{mg} / \mathrm{kg}$ and $5 \mathrm{mg} / \mathrm{kg}$, respectively) was used to maintain anesthesia. The subjects were followed up for 5 days subsequent to the end of irradiation procedure. All animals were monitored closely by the veterinary care staff during this period. The subjects were euthanized with decapitation 5 days after the conclusion of the radiation therapy.

\section{Irradiation procedures}

For the rats in Groups 2 through 6, individual irradiation was administered with an anterior $4 \times 3 \mathrm{~cm}$ single portal to the whole abdomen using a Cobalt-60 treatment unit (CIS Bio International S.A., Gif-sur-Yvette, France) at a sourceto-skin distance of $65 \mathrm{~cm}$. After anesthesia, the subjects were fixed to a $20 \times 30 \mathrm{~cm}$ polystyrene foam treatment couch (Med-Tec, Inc., Orange City, IA) in a supine position. The positioning accuracy of the fields was checked for each rat with a therapy simulator (SIMICS; Mecaserto SA, St Thibault Des Vignes, France). Special dosimetry was performed in irregular fields. The dose homogeneity across the field was found to be $5 \%$. The rats were closely monitored from irradiation until recovery from anesthesia. Equal-field sham irradiation was administered to the rats in Group I.

\section{Histopathological analysis}

The extracted samples were fixed with $10 \%$ neutral buffered formalin for I day and subjected to routine procedures for evaluation under a light microscope. The samples were then embedded in paraffin. Sections of 5-micron thickness were removed from the prepared paraffin blocks, stained with hematoxylin and eosin, and examined microscopically. All examinations were performed by an experienced pathologist. The histopathological evaluation assessed dilatation, atrophy and protein deposition in the tubuli, vacuolization and sclerosis in the glomerulus, and lymphocyte infiltration in the interstitial area $(3,5)$. Renal damage was graded from 0 to 4: 0-no damage, I-very low 
grade damage, 2-low grade damage, 3-moderate damage, and 4-severe damage. Each lesion defined above was graded separately and the values were summed up and divided by 4 (the number of evaluated damage types).

\section{Statistical analysis}

Standard statistical methods were used to analyze the data using the Statistica 7.0 program (Statistica, Inc., Palo Alto, CA, USA). Statistical comparisons between the groups were performed using the one-way analysis of variance (ANOVA) method. One-way ANOVA was followed by a post hoc Bonferroni honest significant difference test. A $P$ value $<0.05$ was considered statistically significant.

\section{RESULTS}

A total of 33 rats were included. During the study, 2 rats from the experimental groups and I rat from the control group died. The average values for renal damage sustained in the groups are provided in Figure I. The mean renal damage values were $0.2 \pm 0.44$ for Group I $(n=5)$, $3.75 \pm 0.5$ for Group $2(n=4), 2.66 \pm 0.5$ I for Group $3(n=6)$, $2.66 \pm 0.51$ for Group $4(n=6), 1.83 \pm 0.40$ for Group 5 $(n=6)$, and $1.83 \pm 0.40$ for Group $6(n=6)$. The renal damage score of the groups that received radiation and the control group were statistically compared $(p<0.001)$. The results indicated that the rate of damage was the same for Groups 3 and 4, as well for as Groups 5 and 6.

A statistically significant difference was identified during comparison of the renal damage between the groups that received RT and the control group $(p<0.001)$. Figure 2 demonstrates the renal tissue in which normal glomerular and tubular structures were present.

The renal histopathology of Groups 2, 4, and 6 can be seen in Figures 3, 4, and 5, respectively. In Figure 3, the tubuli demonstrated dilatation, as well as degeneration in places. This finding was more distinctive in the subcapsular area. Dilatation was particularly prominent in the distal tubuli. Degeneration, on the other hand, was more apparent in proximal tubular cells. The lumens of these tubuli also showed proteinosis material. Deterioration was observed in the glomerular structure in many areas; it was also noted that the integrity between the glomerulus and the Bowman capsule was disrupted and that the glomerulus

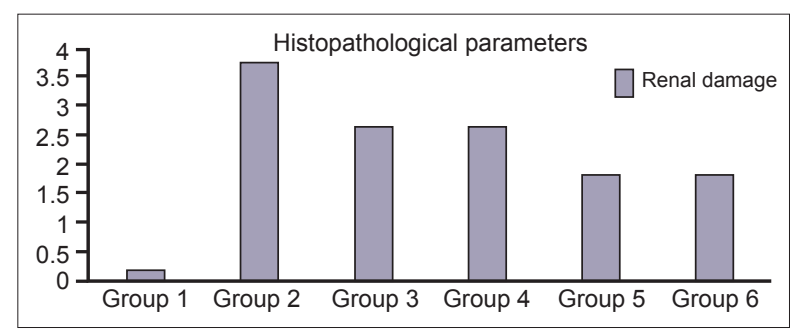

Figure 1. Renal tissue damage parameter values of the groups.

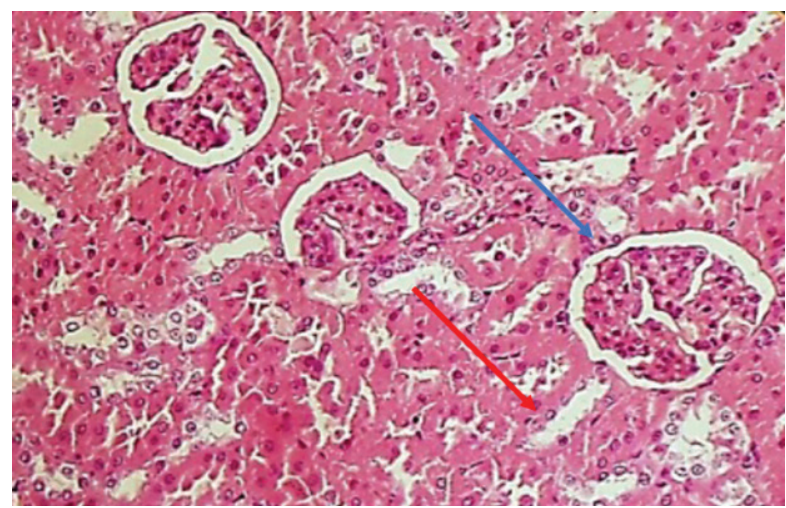

Figure 2. Normal renal tubule and glomerulus morphology were observed in the control group. Blue arrow indicates normal renal glomerulus structure and red arrow indicates normal renal tubule structure (H\&E, x200).

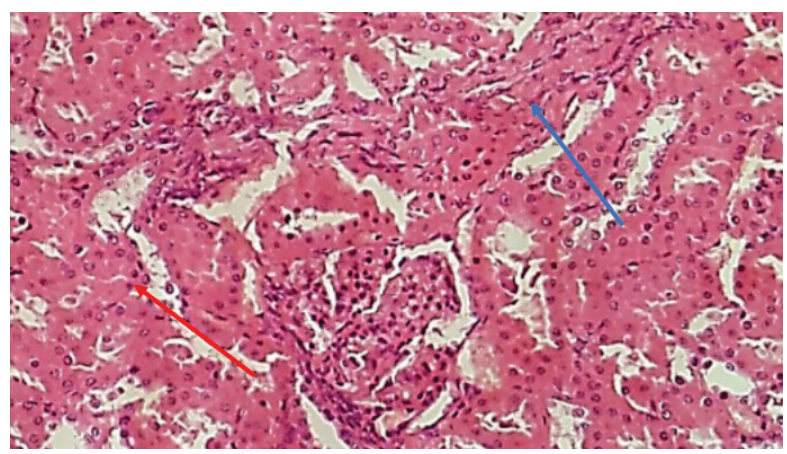

Figure 3. Severe level of irradiation damage was observed in Group 2. Blue arrow indicates interstitial fibrosis area and red arrow indicates severe tubular atrophy (H\&E, x200).

had shriveled in some places. There was slight edema and a connective tissue increase in the interstitial area. Some regions revealed leucocyte infiltration. There was general capillary dilatation and congestion in the kidney. The tubuli also showed dilatation and degeneration in places in Group 4 (Figure 4); however, the findings were less significant in comparison with Group 2. They were mostly limited to the subcapsular region. It was also observed that the glomerular structures were better preserved than those ones in Group 2. In Group 6 (Figure 5), there were lymphocytes in places in the interstitial area. The tubular structure and the glomeruli were observed as generally normal.

In the comparisons between groups illustrated in Table I, there was no statistically significant difference $(p>0.05)$ between the hypofractionated group sets of Groups 3-4 $(2.66 \pm 0.5 \mathrm{I})$ and $5-6(1.83 \pm 0.40)$. However, there was a statistically significant difference in the comparison between Group $2(3.75 \pm 0.5 \mathrm{I})$ and the group sets of Groups $3-4$ and 5-6 $(p<0.05)$.

\section{DISCUSSION}

Abdominal or pelvic radiotherapy is applied to many tumor types. RT is used adjuvantly or palliatively for rectal 


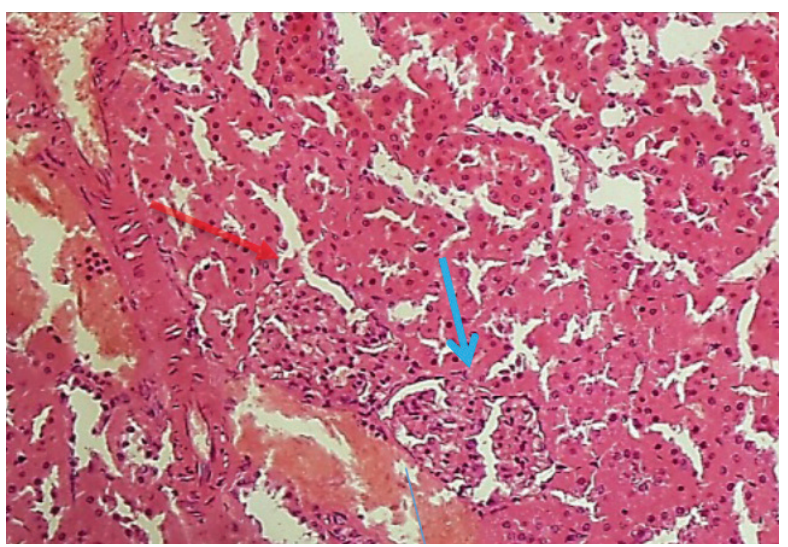

Figure 4. Moderate level of tubular atrophy was observed in Groups 3-4. (H\&E, x200).

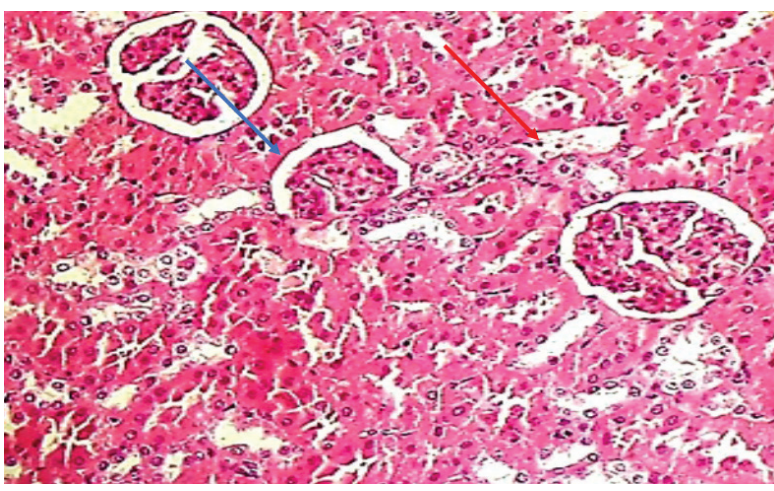

Figure 5. Low grade damage was observed in Group 5. Blue arrow indicates renal glomerulus and red arrow indicates renal tubulus (H\&E, x200).

cancer, prostate cancer, bladder cancer, testicular tumors, lymph node metastases, and soft tissue tumors. Use of modern RT techniques requiring a large number of monitor units, use of photon energies $>10 \mathrm{MV}$, or large fraction size results in higher incidental irradiation to normal tissues. Hypofractionation has been proposed as an additional strategy to optimize the therapeutic ratio. Its effect on the surrounding normal-functioning tissues, however, remains uncertain. Because renal tissues are highly radiosensitive, incidental radiation exposure during abdominopelvic external beam radiotherapy is a significant problem. In the present study, a total radiation dose of 12 Gy was applied as 6, 4, 3, 2, and I.7 Gy daily fractions, and substantial renal damage was initially demonstrated in all rats that received abdominal irradiation. ${ }^{[3]}$
Acute kidney injury (AKI) is a sudden episode of kidney failure or kidney damage that happens within a few hours or days, resulting in the accumulation of nitrogenous products in the blood. AKI can be classified as prerenal, renal, or post-renal. Symptoms may include fatigue, nausea and vomiting. When left untreated, seizures and coma may also occur. An increased tendency to fluid, electrolyte, and acid-base disorders is evident. Treatment is directed at the underlying disease, and generally includes fluid and electrolyte management, and sometimes dialysis. Many causes are reversible with early diagnosis and proper treatment, yet the overall survival rate remains at about $50 \%$ since many patients with AKI have important underlying disorders. The vast majority of survivors have adequate kidney function, while $10 \%$ require dialysis or transplantation (half of those require immediately supportive treatment as renal function slowly deteriorates).$^{[8]}$ Irradiation is an intrinsic renal cause of AKI. AKI injury can be critical and life-threatening in cancer patients. Lastly, it can be a hurdle for optimal cancer treatment or cause interruption of treatment and hospitalization. Therefore, the effort to avoid the onset of AKI during RT is very important in cancer patients being treated with abdominal irradiation.

Radiation nephropathy constitutes irreversible damage with a course of progressive glomerular and tubular changes, which results in glomerulosclerosis and tubulointerstitial fibrosis. Glomerulosclerosis and tubulointerstitial fibrosis, in turn, lead to renal failure..$^{[9]}$ The development mechanism of radiation nephropathy has not been clearly explained yet. While it is known that angiotensin II has an important role in this, the condition is thought to occur due to free radicals. Since it is difficult to measure free radicals in vivo, Robbins et al. assessed DNA oxidation with immunohistochemical methods. A high rate of DNA oxidation was identified 4 weeks after irradiation and for a period of 24 weeks. In the $16^{\text {th }}$ and $24^{\text {th }}$ weeks, the changes arising from RT resulted in glomerulosclerosis and tubular atrophy. ${ }^{[10]}$ In another study, the myofibroblastic activation and transformation in the tissues increased due to tumor growth factor (TGF) release from the tubular epithelium. [II] Studies on rats showed that the TGF level in tissues increases after radiation and that this effect lasts for 24 weeks. ${ }^{\left[{ }^{[2]}\right]}$ All of these effects cause the extracellular matrix to grow (fibronectin, collagen type 3) and result in tubular atrophy and fibrosis.. ${ }^{[12,13]}$ After this study, we believe that the aforementioned effects are the reason short-

Table I. Renal damage value of groups

\begin{tabular}{lcccccc}
\hline & Group I $(n=5)$ & Group $2(n=4)$ & Group $3(n=6)$ & Group $4(n=6)$ & Group $5(n=6)$ & Group $6(n=6)$ \\
\hline Renal damage value & $0.2 \pm 0.44$ & $3.75 \pm 0.5^{b, d, e}$ & $2.66 \pm 0.5 I^{b, c}$ & $2.66 \pm 0.5 I^{b, c}$ & $1.83 \pm 0.40^{b, c}$ & $1.83 \pm 0.40^{b, c}$ \\
\hline
\end{tabular}


term, high-dosage RT (Group 2) caused more renal damage than long-term, low-dosage RT (Groups 3, 4, 5, and 6).

Randomized clinical trials have established that dose-escalated RT improves some cancer types compared with lower-dose radiation controls. ${ }^{[3,13]}$ However, dose-escalated radiation delivered with conventional fractionation (I.8- or 2-Gy fractions) can take 9 weeks to complete. Hypofractionated prostate RT has the potential to deliver a higher biologically effective dose over a shorter period of time compared with conventional fractionation. Shorter hypofractionated treatment is also more convenient for patients by decreasing the cost of treatment and increasing patient access to treatment. On the other hand, theoretically it is thought that hypofractionated abdominopelvic irradiation may increase the incidental testicular radiation dose. However, there are limited prospective data on toxicity after the delivery of moderately hypofractionated regimens, and normal tissue constraints have not been established for hypofractionated treatment. In our study, in which tissue damage was determined by 2 histological parameters, we have demonstrated that hypofractionated abdominal irradiation caused more tissue damage than conventional irradiation. Because this study was not a direct dosimetry study, it is impossible to accurately analyze the impact of different fraction doses on scattered dose received by testicular tissues. Yet, it is possible to conclude that as the fractionated radiation received by the kidneys decreases, the greater the histopathological tissue damage will be.

In conclusion, the present study demonstrated that hypofractionated TAl leads to more prominent acute tissue damage in the kidneys than does conventional irradiation. Although we investigated only the acute effects, using 2 different tissue damage parameters, these acute changes have significant potential to cause late tissue damage. Further studies that measure different parameters are warranted, particularly on the long-term consequences, in order to clarify our results.

Authorship contributions

Concept: H.A.; Design: H.A.; Data collection \&/or proces- sing: H.A.; Analysis and/or interpretation: H.A.; Literature search: H.A.; Writing: H.A.; Critical review: H.A.

Conflict of interest

None declared.

\section{REFERENCES}

1. Curran WJ. Radiation-induced toxicities: the role of radioprotectants. Semin Radiat Oncol 1998;8:2-4.

2. Beauvois S, Van Houtte P. Late effects of radiations on the kidney. Cancer Radiother 1997;1:760-3. [CrossRef]

3. Akdere H, Yurut Caloglu V, Tastekin E, Caloglu M, Turkkan G, Mericliler M, et al. Acute histopathological responses of testicular tissues after different fractionated abdominal irradiation in rats. Postgrad Med 2015;127:73-7. [CrossRef]

4. Dawson LA, Kavanagh BD, Paulino AC, Das SK, Miften M, Li XA, et al. Radiation-associated kidney injury. Int J Radiat Oncol Biol Phys 2010;76:S108-15. [CrossRef]

5. Caloglu M, Yurut-Caloglu V, Durmus-Altun G, Oz-Puyan F, Ustun F, Cosar-Alas R, et al. Histopathological and scintigraphic comparisons of the protective effects of $\mathrm{L}$-carnitine and amifostine against radiation-induced late renal toxicity in rats. Clin Exp Pharmacol Physiol 2009;36:523-30. [CrossRef]

6. Luxton RW. Radiation nephritis. QJ Med 1953;22:215-42.

7. Kiris I, Kapan S, Kilbas A, Yilmaz N, Altuntaş I, Karahan N, et al. The protective effect of erythropoietin on renal injury induced by abdominal aortic-ischemia-reperfusion in rats. J Surg Res 2008;149:206-13.

8. Rewa O, Bagshaw SM. Acute kidney injury-epidemiology, outcomes and economics. Nat Rev Nephrol 2014;10:193-207. [CrossRef]

9. Robbins ME, Wooldridge MJ, Jaenke RS, Whitehouse E, Golding SJ, Rezvani M, et al. A morphological study of radiation nephropathy in the pig. Radiat Res 1991;126:317-27. [CrossRef]

10. Robbins ME, Zhao W, Davis CS, Toyokuni S, Bonsib SM. Radiation-induced kidney injury: a role for chronic oxidative stress? Micron 2002;33:133-41. [CrossRef]

11. Fan JM, Ng YY, Hill PA, Nikolic-Paterson DJ, Mu W, Atkins RC, et al. Transforming growth factor-beta regulates tubular epithelial-myofibroblast transdifferentiation in vitro. Kidney Int 1999;56:1455-67.

12. Robbins ME, O'Malley Y, Zhao W, Davis CS, Bonsib SM. The role of the tubulointerstitium in radiation-induced renal fibrosis. Radiat Res 2001;155:481-9. [CrossRef]

13. Guttman PH, Kohn HI. Progressive intercapillary glomerulosclerosis in the mouse, rat, and Chinese hamster, associated with aging and $\mathrm{x}$ ray exposure Am J Pathol 1960;37:293-307.

\section{Sıçanlarda Böbrek Dokusunda Farklı Fraksiyon Şemalarında Uygulanan 12 Gy Radyoterapinin Yarattığı Akut Etkilerin Histopatolojik Olarak İncelenmesi}

Amaç: Amacımız aralıklı verilen fraksiyone doz radyoterapinin böbrek hasarına etkisini incelemek.

Gereç ve Yöntem: Sıçanlarda 6 gruba randomiz edildi: Grup I: Kontrol; sham radyoterapi ( $n=5)$; Grup 2: Hipo-fraksiyone total abdominal radyoterapi (TAR); total 12 Gy (2 günde 2 fraksiyon) ( $n=4$ ); Grup 3: Hipo-fraksiyone TAR; total 12 Gy (3 günde 3 fraksiyon; $n=6$ ); Group 4: Hipo-fraksiyone TAR; total 12 Gy (4 günde 4 fraksiyon; $n=6$ ); Group 5: konvansiyonel ayırma ile TAR; total 12 Gy (6 günde 6 fraksiyon; $\mathrm{n}=6$ ); ve Group 6: konvansiyonel ayırma ile TAR; total 12 Gy (7 günde 7 fraksiyon; $n=6$ ).

Bulgular: Hipofraksiyone gruplar 3 ile $4(2.66 \pm 0.5 \mathrm{I})$ ve grup 5 ile $6(\mathrm{I} .83 \pm 0.40)$ arasında istatistiksel olarak anlamlı fark tespit edilmezken grup $2(3.75 \pm 0.5 \mathrm{I})$ ile grup 3-4 ve grup 5-6 arasında istatistiksel olarak anlamlı fark tespit edilmiştir $(\mathrm{p}<0.05)$.

Sonuç: Bu çalışmamız hipo-fraksiyone total abdominal radyoterapini, böbreklerde akut doku hasarına konvansiyonel radyoterapiye göre daha belirgin şekilde yol açtı̆̆ını göstermiştir.

Anahtar Sözcükler: Böbrek dokusu; hipo-fraksiyone radyoterapi; radyasyon hasarı; radyoterapi. 